\title{
Histological changes in the cervix of the rabbit after coitus
}

\author{
K. R. Tyler \\ Department of Zoology and Comparative Physiology, University of Birmingham, \\ P.O. Box 363, Birmingham B15 2TT, U.K.
}

\begin{abstract}
Summary. The histology of the rabbit ectocervix was investigated by light, transmission and scanning electron microscopy before and after insemination. The cervix became oedematous and heterophil polymorphs invaded the portio vaginalis within $30 \mathrm{~min}$ of mating or artificial insemination of whole semen, but not after insemination with sperm-free seminal plasma or mating with a vasectomized buck.
\end{abstract}

\section{Introduction}

In the doe, as in women, semen is ejaculated into the vagina and ejaculated spermatozoa must pass through the cervix before reaching the uterine horns or the oviducts. The cervix has been viewed as a sperm reservoir, allowing a slow trickle of spermatozoa into the uterine horns over a prolonged period, and as a sperm haven, where spermatozoa may be relatively safe from uterine phagocytes and the hostile vaginal environment (Mattner, 1966). Others workers have pointed to its role in selection of live from dead spermatozoa (Noyes, Adams \& Walton, 1958). Motility seems to be necessary for rapid and successful transcervical progression of spermatozoa (Mattner, 1969; Lightfoot \& Restall, 1971).

The cervix is immunologically competent, producing antibodies in response to an antigen challenge (Omran \& Hulka, 1971; Lieberman \& Menge, 1971; Behrman \& Lieberman, 1973), and the immunoglobulins IgA and IgG are present and stable in the cervical mucus and tissues (Moghissi \& Neuhaus, 1962; Tjokronegoro \& Sirisinha, 1974). Antibodies to spermatozoa have been demonstrated in cervical mucus, and the passage of spermatozoa through the cervix appears to be sensitive to antibodies (Parish \& Ward, 1968; Metz \& Anika, 1970); Barwin (1974) has reported that uterine insemination can overcome infertility in some women with cervical anti-sperm antibodies.

The invasion of the uterus and vagina of the rabbit by phagocytes in response to semen is well known (review by Austin, 1976). Phillips \& Mahler (1975) investigated this response in the vagina and found that a heterophil invasion occurs within $30 \mathrm{~min}$ of insemination, even when a vasectomized buck was used, suggesting that the effect can be triggered by some agent other than spermatozoa.

In the present investigation, part of a study on the immunological selection of spermatozoa, the cervices from mated and unmated rabbits were examined histologically.

\section{Materials and Methods}

Nineteen New Zealand White does were obtained from Olac Northern Ltd, Redhill Farm, Birming-

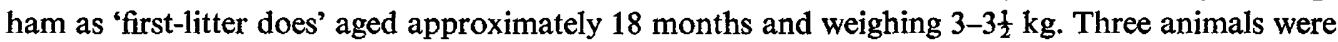
killed unmated, 6 were mated to a single stud buck and killed at various times from $\frac{1}{2}$ to $12 \mathrm{~h}$ post coitum, and 2 were mated with a vasectomized buck and killed $2 \mathrm{~h}$ post coitum. Of the remaining 8 does, 4 were artifically inseminated with $0.25 \mathrm{ml}$ fresh semen, and 4 with seminal plasma separated from the same 4 ejaculates. Seminal plasma was prepared by dilution of semen $1: 1$ with phosphatebuffered saline (Dulbecco 'A'), centrifugation at $600 \mathrm{~g}$ for $15 \mathrm{~min}$, and filtration of the supernatant through a $0 \cdot 22 \mu \mathrm{m}$ millipore filter. All seminal plasma samples were examined microscopically to confirm that spermatozoa were absent. These rabbits were killed $2,4,10$ or $14 \mathrm{~h}$ after insemination. 


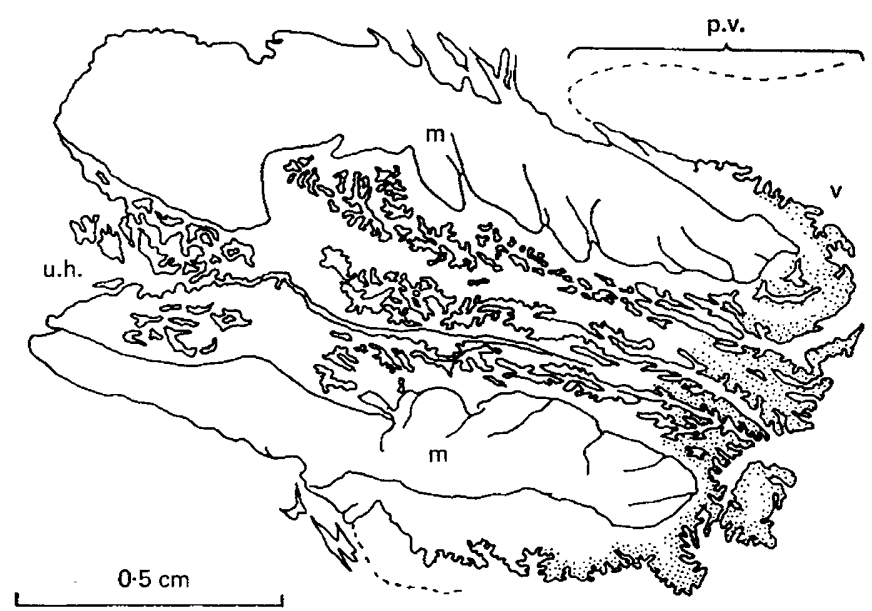

Text-fig. 1. Camera lucida drawing of a longitudinal section through one cervix of a rabbit mated $2 \mathrm{~h}$ before death. The stippled regions show the area invaded by eosinophilic polymorphonuclear cells, demonstrating their confinement to the epithelium and subepithelial connective tissue of the portio vaginalis (p.v.). $\mathrm{m}$, Muscle of the cervix; u.h., uterine horn; $v$, vagina.

Does were deeply anaesthetised by an i.v. injection of 25-35 mg sodium pentobarbitone (Nembutal:Abbott) $/ \mathrm{kg}$. The uterus was exposed by a midline incision and the paired cervices (Pl. 1 , Fig. 1) were excised and placed into ice-cold paraformaldehyde-picric acid fixative (Zamboni \& de Martino, 1967). The animal was then killed by an overdose of Nembutal.

The portio vaginalis of one of each of the paired cervices (see Text-fig. 1) was sliced into $1 \mathrm{~mm}$ thick slices for electron microscopy. The remaining cervix was fixed for $24 \mathrm{~h}$ in the same fixative, embedded in paraffin wax and sectioned at $6-8 \mu \mathrm{m}$ for histological investigations. Sections were stained with haematoxylin and eosin, and with the modified Undritz II stain described by Archer (1963) to distinguish between the different types of granulocytes.

Tissue for transmission electron microscopy was fixed for $\mathbf{3 0} \mathrm{min}$ in paraformaldehyde-picric

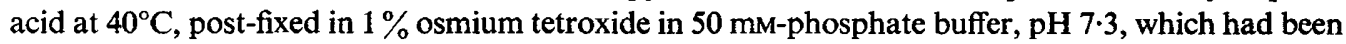
adjusted to 317 mosmol by sucrose addition, and vacuum embedded in Epon 812. Sections (1 $\mu \mathrm{m})$ were taken for light microscopy and stained with toluidine blue; thin ( $900 \AA$ ) sections were taken onto formvar-coated 200-mesh copper grids and stained with uranyl acetate (Stempak \& Ward, 1964) and lead citrate (Reynolds, 1963). Grids were examined in a Philips EM 300 electron microscope at $80 \mathrm{kV}$.

\section{EXPLANATION OF PLATE 1}

Fig. 1. The paired ectocervices in situ of a rabbit mated $14 \mathrm{~h}$ previously: note the oedematous state of the portio vaginalis of both cervices.

Fig. 2. Scanning electron micrograph of a small area of the epithelium of the portio vaginalis. Note the three secretory cells, with apical microvilli, surrounded by ciliated cells.

Fig. 3. The epithelium and subepithelial connective tissue of the portio vaginalis of an unmated rabbit. Resin section, toluidine blue stain.

Fig. 4. A portion of the same epithelium as shown in Fig. 3 examined in the electron microscope. Ciliated cells with electron-transparent cytoplasm, and secretory cells with electron-dense cytoplasm and large vesicles can be distinguished.

Fig. 5. A section of the same tissue as shown in Fig. 3, cut parallel to the basement membrane of the epithelium, showing the large amount of Golgi complex present in the ciliated cells.

Fig. 6. The epithelium of the portio vaginalis of a rabbit mated $6 \mathrm{~h}$ previously, showing the invasion of polymorphonuclear granulocytes into the epithelium. 

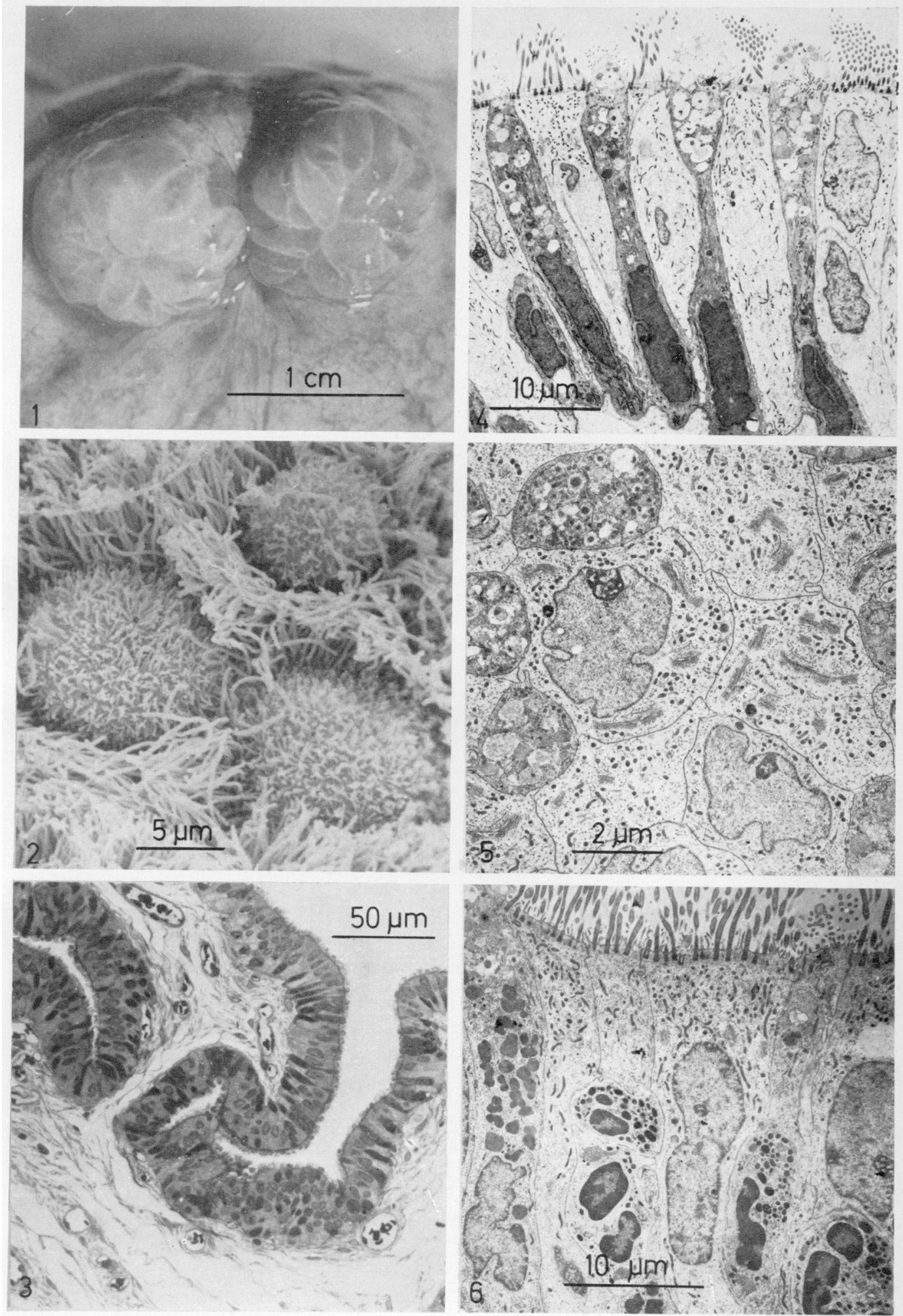

( Facing p. 342) 
A small piece of the portio vaginalis of several of the samples was fixed in paraformaldehydepicric acid, dehydrated through alcohols and dried at critical point, using the $\mathrm{CO}_{2}$ method described by Cohen (1974) and amyl acetate as the intermediate fluid. The tissue was attached to stubs with double-sided Sellotape, gold-coated, and examined on a scanning electron microscope (Cambridge Stereoscan) at a variety of magnifications.

\section{Results}

The epithelium of the portio vaginalis, and of the cervical canal, was columnar in form, consisting of two types of cells (Pl. 1, Figs 3, 4, and 5). Those of the first type were ciliated, with small apical microvilli between the cilia. These cells had a relatively electron-transparent cytoplasm with many elongated mitochondria, and generally contained many Golgi complexes (PI. 1, Fig. 5). The cytoplasm stained only lightly with toluidine blue or eosin. The second cell type was typically mucus-secreting in appearance, with many large single membrane-bound vesicles with dense cores, and with a much more electron-dense cytoplasm containing abundant rough endoplasmic reticulum and Golgi complex. These cells appeared to be scattered amongst the ciliated cells, with occasional small clusters in some areas, and they stained heavily with toluidine blue, but not with eosin. The vacuoles took up neither stain. Scanning electron microscopy of the epithelium (Pl. 1, Fig. 2) revealed a similar pattern, confirming the distribution of the secretory cells and the presence of apical microvilli.

When the cervix was examined after mating with a normal buck and compared with the tissues of unmated animals, several differences were apparent. There was always some degree of oedema of the portio vaginalis and a massive invasion of polymorphonuclear cells into the epithelium and subepithelial connective tissues. These cells, $6-8 \mu \mathrm{m}$ in diameter, were found in all of the mated animals examined, and were present by $\frac{1}{2} \mathrm{~h}$ post coitum in numbers in excess of $10^{6}$ cells $/ \mathrm{mm}^{3}$. They were also present in all of the animals which had been inseminated with whole semen: none was found in does inseminated with seminal plasma only, or in any region of the cervix other than the portio vaginalis. When tissues from the two animals mated with the vasectomized buck were examined, there was no apparent reaction in the cervix of one doe; in the other there was no oedema of the portio vaginalis but polymorphs were present although in reduced numbers (approximately $10^{3} \mathrm{cells} / \mathrm{mm}^{3}$ ). The polymorphs contained deposits of a material believed to be glycogen, and eosinophilic granules (P1. 1, Fig. 6) which were phase dense when examined by phase-contrast microscopy and did not stain with the Undritz II stain, although similar granules in blood eosinophils in the vessels stained greenishbrown. In the transmission electron microscope, these granules were electron dense, even before heavy-metal staining, amorphous, and with a single boundary membrane. Polymorphs were seen in capillaries of the subepithelial connective tissues, and several were seen apparently migrating through the walls of the capillaries in the samples taken at $4 \mathrm{~h}$ post coitum and earlier.

\section{Discussion}

The invasion of the rabbit cervix by polymorphs is clearly triggered by some component of semen other than seminal plasma. When whole semen was placed in the vagina by natural mating or artificial insemination, the portio vaginalis was heavily infiltrated by polymorphs; when no mating was allowed, or when seminal plasma was used, none of these cells was found. The slight response seen in one of the does mated with a vasectomized buck could perhaps have been triggered by seminal bacteria or bacterial products because a similar uterine response to bacteria has been described by Rowson, Lamming \& Fry (1953).

The cell invasion in the rabbit is very rapid and polymorphs were found in the cervix by $\frac{1}{2} h$ after mating. Mattner (1968) reports the presence of leucocytes in the goat cervix before and $24 \mathrm{~h}$ after insemination, but the numerical changes following coitus were small compared with those found for the rabbit. Nellor \& Brown (1966) describe eosinophil-like cells in the genital tract tissues of cattle and other animals after hormonal treatment as 'degenerating plasma cells', and suggest that 
they are tissue-derived rather than blood cells. No evidence to support this view was seen in the present study: the presence of polymorphs in blood vessels and in the walls of capillaries suggests that they are blood-derived or blood-borne. The absence of obvious crystalline inclusions in the granules of the polymorphs at the ultrastructural level, the lack of staining with the Undritz II peroxidase stain and the eosinophilia all point to these cells being blood heterophils, according to the classification used by Schermer (1967). This conclusion supports that of Phillips \& Mahler (1975), who found a similar invasion of the vaginal wall of the rabbit within $\frac{1}{2} h$ of coitus. These authors did, however, report that leucocytosis also occurred after mating with a vasectomized buck.

The cellular invasion and oedema in the rabbit might be triggered by the interaction of spermatozoa with natural anti-sperm globulins which are known to coat spermatozoa in the female tract (Symons, 1967; Cohen \& Werrett, 1975). It has been suggested that this interaction occurs preferentially with dead and dying spermatozoa (Symons, 1967) and may reflect the culling of 'genetically defective' spermatozoa (Cohen \& Werrett, 1975) or the processing of sperm antigens in a nonimmunogenic way (Johnson, 1973).

I am grateful to the M.R.C. for support through a Research Training Award, Dr M. P. Osborne and Mrs J. Birch for technical help, and Dr J. Cohen.

\section{References}

ARCHER, R.K. (1963) The Eosinophil Leucocytes. Blackwell, Oxford.

Austin, C.R. (1976) Fate of spermatozoa in the female genital tract and the problem of induction of local anti-sperm immunity in women. Proc. 3rd Int. Symp. Immunol. Reprod., Varna, Bulgaria, pp. 63-80. Scriptor, Copenhagen.

BARWIN, B.N. (1974) Intrauterine insemination of husband's semen. J. Reprod. Fert. 36, 101-106.

Behrman, S.J. \& Lieberman, M.E. (1973) Biosynthesis of immunoglobulins by the human cervix. In Biology of the Cervix, pp. 235-250. Eds R. J. Blandau \& K. Moghissi. University of Chicago Press.

Conen, A.L. (1974) Critical point drying. In Principles and Techniques of Scanning Electron Microscopy, pp. 44-112. Ed. M. A. Hayat. Van Nostrand Reinhold, New York.

CoHen, J. \& WerretT, D.J. (1975) Antibodies and sperm survival in the female genital tract of the mouse and the rabbit. $J$. Reprod. Fert. 42, 301-310.

Johnson, M.H. (1973) Physiological mechanisms for the immunological isolation of spermatozoa. Adv. Reprod. Physiol. 6, 279-323.

LIEBERMAN, M.E. \& MeNGe, A.C. (1971) Immunoglobulins and antifertility effects of rabbit uterine secretions. Proc. 2nd Int. Symp. Immunol. Reprod., Varna, Bulgaria, p. 207. Ed. K. Bratanov. Academic Press, New York.

LightFoOt, R.J. \& Restall, B.J. (1971) Effects of site of insemination, sperm motility and genital tract contractions on transport of spermatozoa in the ewe. $J$. Reprod. Fert. 26, 1-13.

MATTNER, P.E. (1966) Formation and retention of the spermatozoan reserve in the cervix of the ruminant. Nature, Lond. 212, 1479.

MatTNer, P.E. (1968) The distribution of spermatozoa and leucocytes in the female genital tract in goats and cattle. J. Reprod. Fert. 17, 253-261.
MATTNER, P.E. (1969) Comparison of the distribution of motile and immotile spermatozoa in the ovine cervix. Aust. J. biol. Sci. 22, 1069-1070.

METZ, C.B. \& ANIKA, J. (1970) Failure of conception in rabbits inseminated with non-agglutinating univalent antibody-treated semen. Biol. Reprod. 2, 284290.

Moghissi, K.S. \& Neuhaus, O.W. (1962) Composition and properties of human cervical mucus. $A m$. J. Obstet. Gynec. 83, 149-155.

Nellor, J.E. \& Brown, J.E. (1966) Leucocytelike cells in the vagina and uterus, and their modification during the estrous cycle and by progestin and estrogen treatment. Anat. Rec. 155, 591602.

Noyes, R.W., Adams, C.E. \& Walton, A. (1958) Transport of spermatozoa in the uterus of the rabbit. Fert. Steril. 9, 288-299.

OMRAN, K.F. \& HuLKA, J.F. (1971) Infertility associated with local antibody response against sperm in bovine uterine cervix. Int. J. Fert. 16, 195-199.

Parish, E.E. \& WARD, A. (1968) Studies of cervical mucus from infertile women. J. Obstet. Gynaec. Br. Commonw. 75, 1089-1100.

Phillips, D.M. \& MaHler, S. (1975) Migration of leucocytes and phagocytosis in rabbit vagina. $J$. Cell Biol. 67, 334a.

ReYNolds, S. (1963) The use of lead citrate at high pH as an electron opaque stain in electron microscopy. J. Cell Biol. 17, 208-211.

Rowson, L.E.A., LAMming, G.E. \& FRY, R.M. (1953) The relationship between ovarian hormones and uterine infection. Vet. Rev. 65, 335-340.

SCHERMER, S. (1967) The Blood Morphology of Laboratory Animals, pp. 10-11. F. A. Davis Co. Philadelphia.

Stempak, J.G. \& WARD, R.T. (1964) An improved staining method for electron miçroșçopy. J. Cell Biol. 22, 697-701. 
SYmons, D.B.A. (1967) Immunofiuorescent study of the antigenicity of mammalian spermatozoa. Ph.D. thesis, University of London.

Tiozronegoro, A. \& Sirishmen, S. (1974) Degradation of immunoglobulins by secretions of human reproductive tracts. J. Reprod. Fert. 38, 221225.

ZAMBONI, L. \& DE MARTINo, C. (1967) Buffered picric acid-formaldehyde: a new, rapid fixative for electron microscopy. J. Cell Biol. 35, 148 A.

Received 21 September 1976 